\title{
Nutritional and Seed Responses of Forage Kochia to Ruminal Incubation
}

\author{
Forage kochia may be a complimentary forage \\ to most dormant cool-season grasses in the Intermountain West.
}

\author{
By Christopher S. Schauer, David W. Bohnert, \\ Michael F. Carpinelli, and Stephanie J. Falck
}

$\mathrm{I}$

$n$ the northern Great Basin, annual feed costs represent a major obstacle to beef producers and threaten the future of beef production. Feed costs, including hay: and supplement, can range from $\$ 100$ to $\$ 200$ per cow each year. In addition, much of the range in the northern Great Basin is becoming infested with cheatgrass due to past overgrazing and/or reoccurring wildfires. Planting forage kochia on rangelands or pastures may provide a complimentary forage that can decrease winter supplementation costs while aiding in fire prevention.
Forage kochia is a half-shrub native to the arid and semiarid regions of central Eurasia. Because of its natural ability to survive in arid climates and on saline soils, many scientists and rangeland managers consider forage kochia a prime candidate for use in western range rehabilitation and fire prevention efforts.

Forage kochia tends to slow the spread of wildfires when used as a greenstrip; however, it will burn if surrounded by sufficient fuel. Following burning, it will sprout and regrow and is used ex-

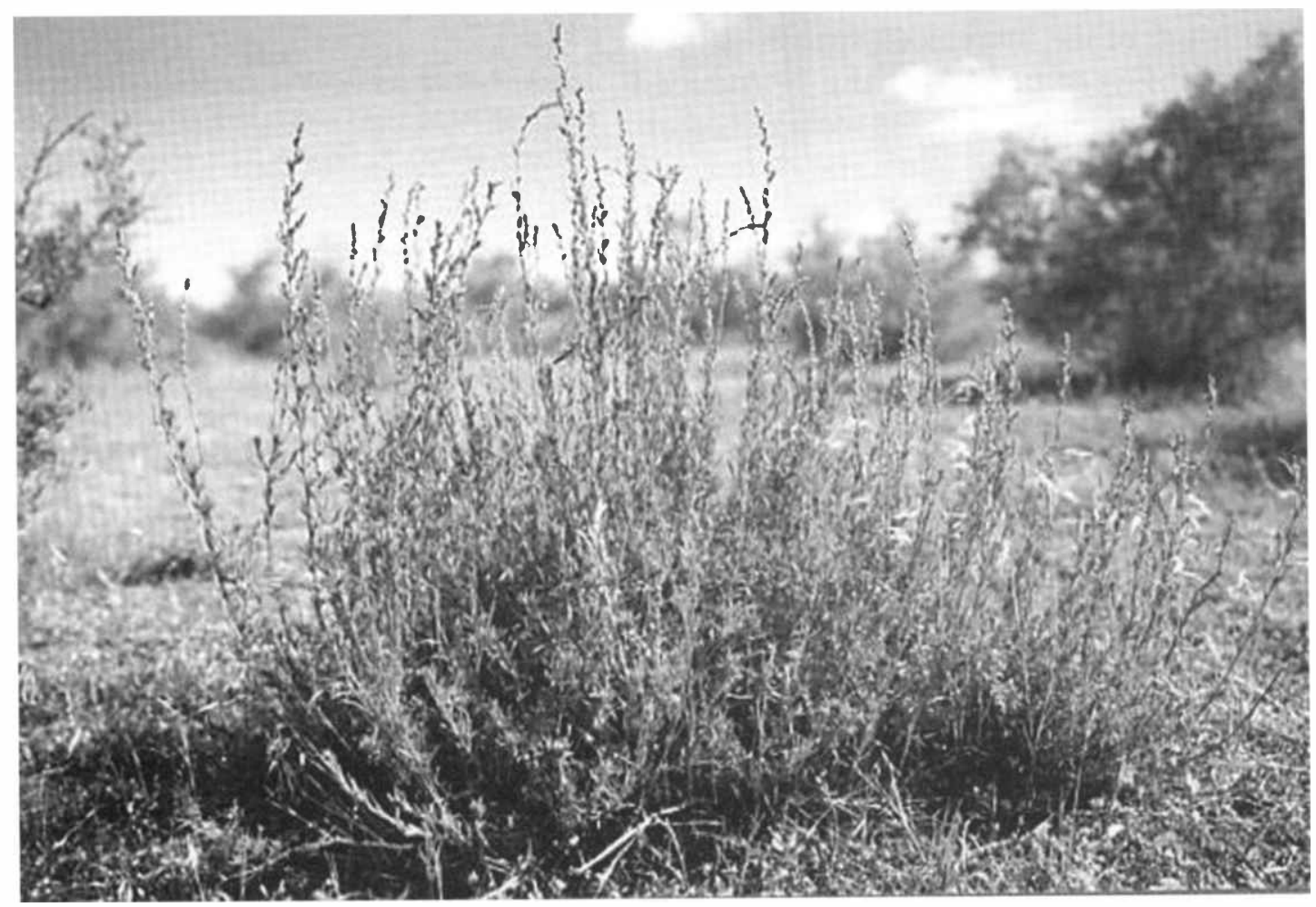

Forage kochia 


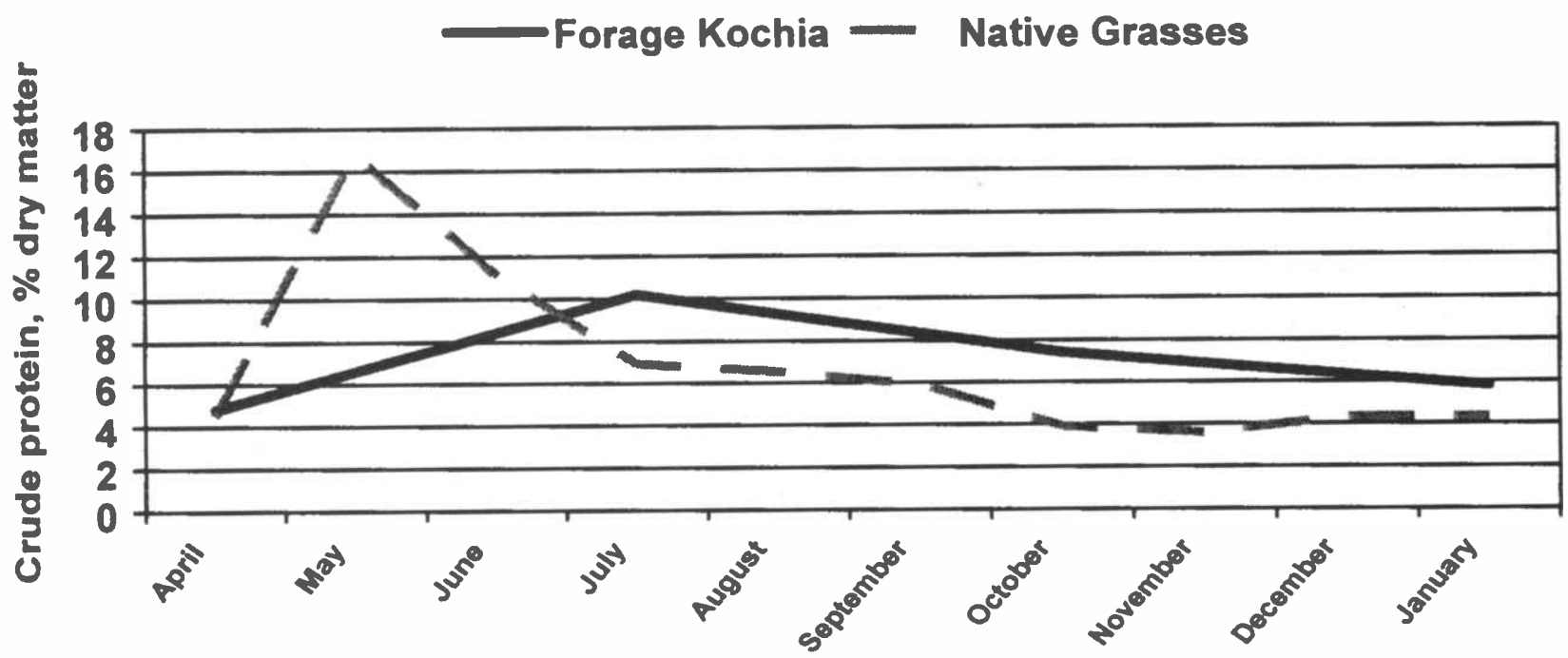

Fig. 1. Effect of calendar date on crude protein concentration of forage kochia.

tensively for seeding after fires on cheatgrass-dominated rangelands to help prevent future wildfires. One concern is that forage kochia will become invasive on rangelands, but recent research has suggested this is not likely. No research, however, has determined if forage kochia seeds consumed by ruminants have the ability to germinate after passage through the digestive tract.

Forage kochia has been promoted as a year-round grazing plant that survives, and even benefits, from persistent grazing up to $70-80 \%$ utilization (1). However, very little research has explored the nutritional quality of forage kochia. Davis (1979) reported crude protein levels ranging from $15 \%$ in August to $9 \%$ in March (dry matter basis). Welch and Davis (1984) reported the in vitro digestibility of 13 accessions of forage kochia. In vitro digestibility ranged from 20 to $38 \%$ across accessions, but did not vary significantly by collection date (February and April) or among accessions.

Forage kochia may improve the nutritional quality of rangeland for domestic livestock and wildlife while decreasing winter supplementation costs. However, to be accepted and implemented by range managers and livestock producers as a sustainable management alternative, the nutritional quality and germination following consumption of seeds of forage kochia must be documented.

\section{Data Collection}

We collected samples of forage kochia for placement in the rumen of cattle to determine forage quality and seed viability. In 1986 and 1987, forage kochia was established on plots 1.2 miles north of Mud Lake in the Harney Basin of southeastern Oregon. These plots were fenced and excluded from cattle grazing but were accessible to wildlife. Approximately twenty plants were clipped on the $15^{\text {th }}$ of July 2001, October 2001, January 2002, and April 2002. Clipped samples were ground to pass through a $2-\mathrm{mm}$ screen in a Wiley mill and placed in Dacron bags. Dacron bags were suspended in the rumen of four ruminally cannulated steers for 0,2 , $8,12,24$, and 96 hours to determine the effects of calendar date on in situ degradation kinetics of dry matter and crude protein.

Five other ruminally cannulated steers were used to determine the viability of forage kochia seeds following ruminal incubation. Fresh forage kochia seeds were placed in monofilament nylon bags, incubated for 16 hours at $102^{\circ} \mathrm{F}$ in pepsin solution, and placed in the rumen for 0,48 , and 96 hours. The seeds were dried at $95^{\circ} \mathrm{F}$ for 72 hours (approximately 2 to $6 \%$ moisture) and viability and mean germination time values were determined.

\section{Nutritional Calendar}

Forage kochia crude protein concentrations were higher in July through January than has been report- 
Table 1. Effect of calendar date on ruminal digestibility of forage kochia.

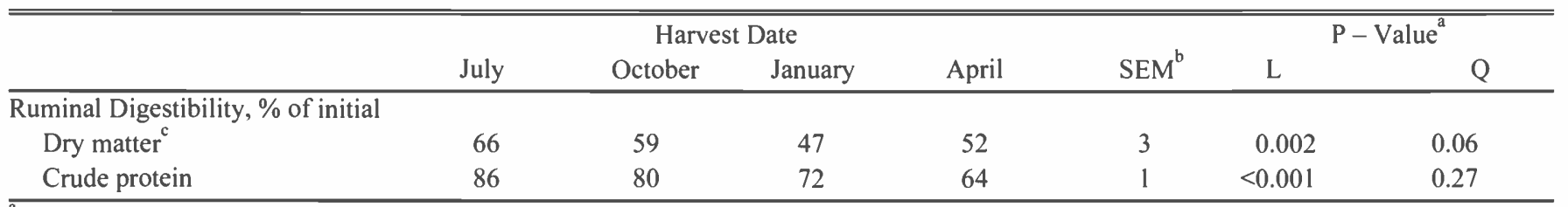

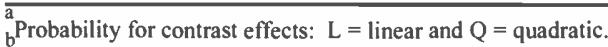

Standard Error of Mean; $n=4$.

Calculated as $\%$ of initial neutral detergent fiber digested.

ed for seven grasses commonly found within the northern Great Basin (2; Figure 1). During periods when native cool-season grasses were actively growing, forage kochia crude protein concentration was lower than native grasses. These results suggest that forage kochia may function as a complimentary forage source to grazing animals during periods when native grasses are dormant, supplying needed protein to both wildlife and domestic livestock. However, forage kochia crude protein levels reported here are lower than those reported by Davis (1979). Differences in stand age and degree of herbivory may account for differences between our results and those of Davis (1979).

Ruminal digestibility of dry matter and crude protein decreased linearly from July 2001 through April 2002 (Table 1; additional data available in Schauer and Bohnert, 2003). However, these levels would increase ruminally digestible dry matter and crude protein available to ruminants grazing dormant native range. Our results for dry matter digestibility are higher than those reported by Welch and Davis (1984). Differences between trials may be the result of differences between accessions, climate, soils, or stand age.

\section{Ruminal Incubation}

Following incubation in the rumen of steers, germination for the 48 and 96 hour samples was $0 \%$, compared to $95 \%$ germination of the non-incubated seeds. Other research has reported that annual kochia had $6 \%$ germination following 24 hour ruminal incubation (3). However, redroot pigweed, common lambsquarters, wild buckwheat, and round-leaved mallow had germination ranging from 15 to $40 \%$ following 24 hour ruminal incubation (3). Our results are encouraging because they demonstrate the inability of forage kochia to become an invasive, noxious weed via ruminant dispersal.

\section{Future Considerations}

Currently, forage kochia has been seeded on approximately 150,000 acres in 10 western states, primarily for use as a reclamation species in highly erodable soils and as greenstrips for the prevention of wildfires. However, its impact on livestock and wildlife performance and distribution has not been documented. Additionally, further research is needed to determine optimum inter-seeding techniques so that private landowners may establish this complimentary forage into current forage stands.

Forage kochia can function as a complimentary forage for domesticated livestock and wildlife grazing dormant cool-season forage in the northern Great Basin without increasing potential stand spread through dispersal of viable seeds following grazing. During periods of native grass dormancy, forage kochia may improve the dietary crude protein of wildlife and domesticated livestock grazing rangelands inter-seeded with forage kochia.

Furthermore, forage kochia has the potential to be a sustainable management alternative by which livestock producers in the northern Great Basin can decrease winter supplementation costs, help stabilize erodable soils, and aid in suppressing wildfires.

\footnotetext{
About the Authors: At the time of this research, Christopher S. Schauer was a graduate student, Eastern Oregon Agricultural Research Center, Oregon State University, Burns, Oregon 97720. He is now with the Hettinger Research and Extension Center in Hettinger, North Dakota. David W. Bohnert is an Animal Scientist, Eastern Oregon Agricultural Research Center, Oregon State University, Burns, Oregon 97720; Michael F. Carpinelli is a Rangeland Scientist, Eastern Oregon Agricultural Research Center, USDA-ARS, Burns, Oregon 97720; and Stephanie J. Falck is a Research Technician, Eastern Oregon Agricultural Research Center, USDA-ARS, Burns, Oregon 97720.
}

(Continued on page 11). 
The Eastern Oregon Agriculture Research Center, including the Burns and Union Stations, is jointly funded by the Oregon Agriculture Experiment Station and USDA-Agriculture Research Service. The authors recognize AAA Land and Livestock for partial support for this research.

\section{References}

1. Herbel, C.H., R.R. Barnes, H.F. Heady, and L.N. Purdy. 1981. Range research in the Soviet Union. Rangelands. 3:61-63.

2. Ganskopp, D. and D. Bohnert. 2001. Nutritional dynamics of 7 northern Great Basin grasses. J. Range Manage. 54:640-647.

3. Blackshaw, R.E. and L.M. Rode. 1991. Effect of ensiling and rumen digestion by cattle on weed seed viability. Weed Sci. 39:104-108.

\section{Additional Reading}

Davis, A.M. 1979. Forage quality of prostrate Kochia compared with three browse species. Agron. J. 71:822-824.

Harrison, R.D., N.J. Chatterton, B.L. Waldron, B.W. Davenport, A.J. Palazzo, W.H. Horton, and K.H. Asay. 2000. Forage Kochia: Its compatibility and potential aggressiveness on intermountain rangelands. Utah Ag. Exp. Sta. Res. Rep. 162. Utah State Univ., Logan, Utah. 843224800. 66p.

Schauer, C.S. and D.W. Bohnert. 2003. The effect of calendar date on in situ NDF and CP degradation characteristics of forage kochia (Kochia prostrata). Proc. Soc. Range Manage. Abstract \#242.

Welch, B.L. and J.N. Davis. 1984. In vitro digestibility of Kochia prostrata (L.) Schrad. Great Basin Naturalist 44:296-298.

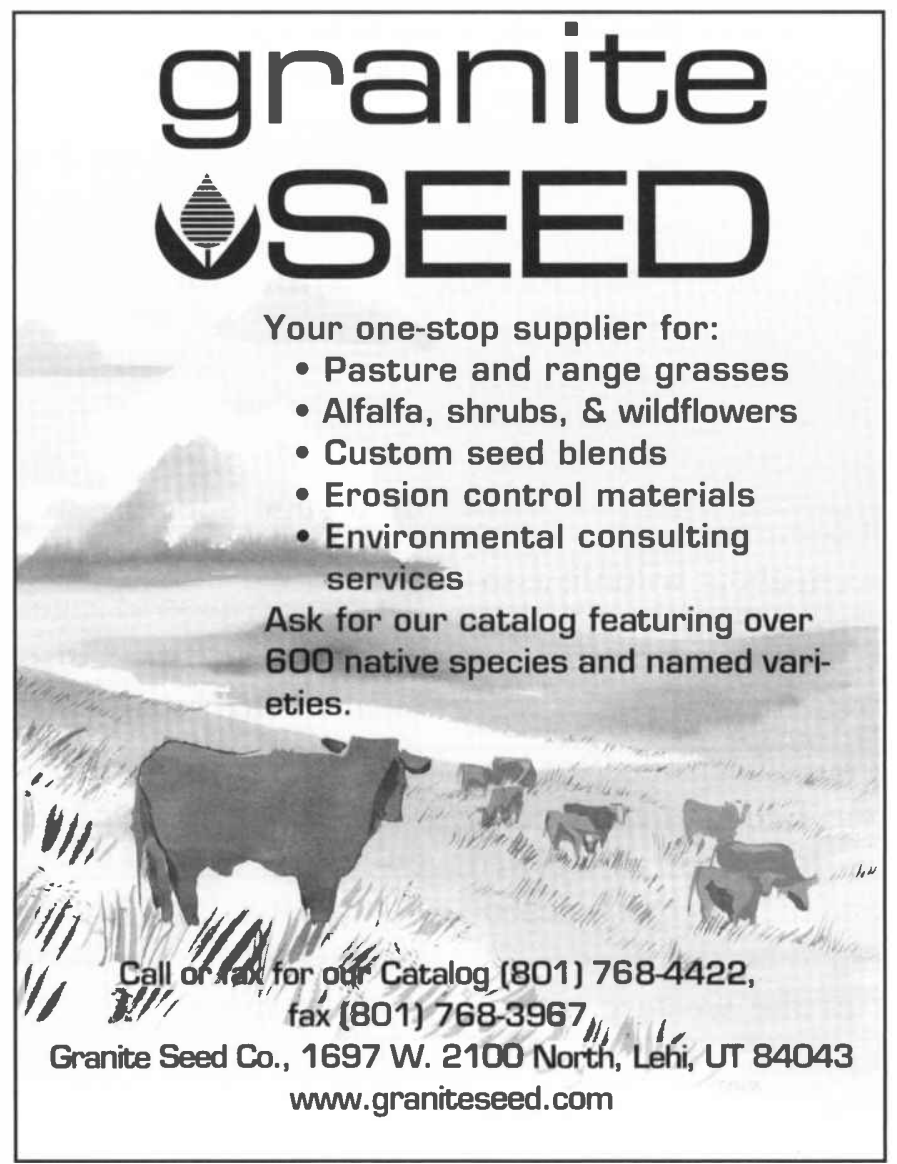

